\title{
Diversity Pattern of Butterfly Communities (Lepidoptera, Papilionoidae) in Different Habitat Types in a Tropical Rain Forest of Southern Vietnam
}

\author{
Lien Van $V u^{1}$ and Con Quang $V^{2}$ \\ ${ }^{1}$ Department of Biology, Vietnam National Museum of Nature, 18 Hoang Quoc Viet, Nghia Do, Cau Giay, Hanoi, Vietnam \\ ${ }^{2}$ Department of Insect Ecology, Institute of Ecology and Biological Resources, 18 Hoang Quoc Viet, Nghia Do, Cau Giay, Hanoi, Vietnam
}

Correspondence should be addressed to Lien Van Vu, vulien@gmail.com

Received 26 January 2011; Accepted 1 March 2011

Academic Editors: M. Griggio and V. Tilgar

Copyright (C) 2011 L. V. Vu and C. Quang Vu. This is an open access article distributed under the Creative Commons Attribution License, which permits unrestricted use, distribution, and reproduction in any medium, provided the original work is properly cited.

\begin{abstract}
Diversity of butterfly communities of a tropical rain forest of Bu Gia Map National Park in South Vietnam was studied in four different habitat types (the natural forest, the disturbed forest, the bamboo forest, and the stream sides in the forest) in December 2008 and April 2009. A total of 112 species with 1703 individuals of Papilionoidae (except Lycaenidae) were recorded. The proportion of rare species tends to decrease from the natural forest to the stream sides, while the proportion of common species tends to increase from the natural forest to the stream sides. The stream sides have the greatest individual number, while the disturbed forest contains the greatest species number. The bamboo forest has the least species and individual numbers. The stream side environment in the forest plays an important role in conserving butterfly abundance while the bamboo shows the poorest butterfly diversity.
\end{abstract}

\section{Introduction}

In general, insect diversity is highest in habitats with the most plant diversity and is lowest in shrub, grass and open areas [1]. The diversity of beetle and some moth groups is high in natural forests and low in secondary forests $[2,3]$. Butterfly diversity, however, is usually lower in natural forests, higher in disturbed forests, and highest in moderately disturbed forests [4-8], or forest edges [9, 10]. Other studies have also indicated that the numbers of butterfly species and individuals are high in disturbed and regenerating forests and low in natural forests [11, 12]. Warren [13] indicated that there were few butterfly species in the habitat with thick forest canopy and, vice versa, more butterfly species in the habitat with less forest canopy. Diversity of butterflies increases with increasing of habitat scale and vegetation structure complex [14]. This shows that a forest habitat with more forest canopy layers and high vegetation diversity supports more insect species than a forest habitat with less forest canopy layers and less vegetation diversity.

The diversity of butterfly communities has been studied in different habitat types in different parts of the world including tropical forest of Southeast Asia. However, there have not been many studies on the diversity of butterfly communities in tropical forests within different habitat types including stream sides in the forest. Stream side habitats in the forest may play an important role in conserving a portion of tropical biodiversity, of which insects are a major part, but little data is available. The forest edge which has more exposure to the open also has the greatest diversity of butterflies [10]. The gaps in the forest have higher diversity of butterflies than the closed forest areas [15]. The stream sides with more open space should therefore have a high diversity of butterflies.

The hypothesis of this study is that the stream sides in the forest have the greatest butterfly diversity; the bamboo forest has the lowest community diversity. 


\section{Materials and Methods}

2.1. Site Study. Research was carried out in Bu Gia Map National Park, Binh Phuoc province, southern Vietnam $\left(12^{\circ} 08^{\prime}-12^{\circ} 17^{\prime}\right.$ North and $107^{\circ} 03^{\prime}-107^{\circ} 14^{\prime}$ East). The Park has $26,032 \mathrm{ha}$ of the protected area and 12,000 ha of buffer zone. The natural forest of the park is $21,376 \mathrm{ha}$, of which 388 ha of rich forest, 2,798 ha of medium forest, 1,692 ha of poor forest, 5,064 ha of mixed forest, and 11,434 ha of bamboo forest. The forest has two main forest types which are tropical moisture deciduous closed forest and tropical wet evergreen closed forest. The park was founded in 2002 and located in the north east of Binh Phuoc province, Dak Nong province in the east, frontier of Vietnam and Cambodia in the north west. The average altitude is $300-700 \mathrm{~m}$ with the highest peak of $738 \mathrm{~m}$.

The study was conducted from 20 to 30 December 2008 and from 10 to 25 April 2009.

2.2. Sampling Method. A modification of the line transect count [16] was used to determine species richness and abundance of butterfly communities in different habitats. The transect method was used in Vietnam in previous works $[10,15,17]$. The method may pose some problems for assessing species richness and relative abundance of butterflies in tropical rain forests; however, this is a suitable method for surveying butterflies in a wide range of habitats including tropical rain forests $[10,18,19]$.

Transect surveys took place between 9:00 am and 4:00 pm on fine days. It took about an hour for each transect. Transects were counted once to twice daily. The sample times for each transect were alternated from day to day, to reduce the effect of different monitoring times on the data recorded. The surveyors walked at a uniform pace and recorded all butterflies of Papilionoidae (except Lycaenidae family) seen within an imaginary $10 \mathrm{~m} \times 10 \mathrm{~m} \times 10 \mathrm{~m}$ box. The transects were restricted to the road, the stream sides in the forest and the forest path. Total 100 counts were taken for 4 transects.

Four 500-m transects were set up in four different habitat types. The vegetation of each habitat type is summarized, with the vegetation identification and nomenclature following Pham [20].

Natural forest $(\mathrm{NF})$ : there are a variety of plant species with diameter from 30 to $45 \mathrm{~cm}$, the canopy height of 30 $35 \mathrm{~m}$. The forest canopy is $70 \%$. The main plant species are Metadina trichotoma (Rubiaceae), Lagerstreoemia calyculata, Lagerstroemia angustifolia (Lythraceae), Albizzia chinensis (Mimosaceae), Combretum quadragulare (Combretaceae), Dalbergia mammosa (Fabaceae), Horsfieldia amygdalina (Myristicaceae), Irvingia malayana (Ionanthaceae), Balakata baccata, Mallotus tetracocus (Euphorbiaceae), Tetrameles nudiflora (Datisceae), Sandoricun koetjape, Swietenia sp. (Meliaceae), Hopea odorata, Anisoptera spp., Dipterocarpus alatus (Dipterocarpaceae), and others.

Disturbed forest (SF): there are a variety of plants from plants of natural forest to light-preferred quick growing plants, shrubs and grasses, and some bamboos. The forest canopy height ranges $20-35 \mathrm{~m}$, and forest canopy is $50 \%$.
The main plant species are quadragulare (Combretaceae), Dalbergia mammosa (Fabaceae), Horsfieldia amygdalina (Myristicaceae), Irvingia malayana (Ionanthaceae), Bombax aceps (Bombacaceae), Balakata baccata (Euphorbiaceae), Tetrameles nudiflora (Datisceae), Dipterocarpus alatus (Dipterocarpaceae), and others.

Stream sides (SS): two sides along the "Dac O" stream with the wideness of $20-25 \mathrm{~m}$. The vegetation is broad leaf evergreen plants with diameter of $15-40 \mathrm{~cm}$, the canopy height of $15-30 \mathrm{~m}$. The main plant species are Anisoptera spp. (Dipterocarpaceae), Dalbergia (Fabaceae), plants of Anonaceae, Euphorbiaceae and other families, and shrubs and grasses along the stream sides. The forest canopy is $30 \%$.

Bamboo forest (BF): the bamboo forest consists of 80 $90 \%$ bamboos with the canopy height of $10-25 \mathrm{~m}$. The bamboo forest canopy is $60 \%$. The main bamboo species is Bambusa balcoa.

2.3. Data Analysis. Indices of diversity, evenness, and species richness of butterfly communities were assessed for each habitat type, and calculated using Primer v5 software [21] running in Window Vista. The similarity of species composition between habitat types (Bray-Curtis similarity with square root transformation) was analyzed with Cluster Analysis using Similarity Tree software [21].

Identification and nomenclature of butterfly species were followed, Chou [22], D'Abrera [23], and Monastyrskii and Devyatkin [24].

\section{Results}

A total of 112 different species with 1703 individuals of butterflies were recorded in four different habitat types in the studied period in 2008-2009. The butterfly list and their abundance are presented in Table 1 . The major number of species contain the lowest individual numbers with 61 species (54\% of all species) showing individuals less than 5 for all 4 transects. The two most abundant species are Catopsilia pomona (231 individuals) and Ypthima baldus (273 individuals). The greatest number of individuals of Catopsilia pomona occurred in the stream sides with 170 individuals, while most of the individuals of Ypthima baldus are found in the disturbed forest and bamboo forest with 145 and 122 individuals, respectively.

Figure 1 indicates that the proportion of rare species (R) tends to decrease from the natural forest to the stream side environment or from the thickest forest canopy to the least forest canopy. The proportion of common species (C) tends to increase from the natural forest to the stream sides. The proportion of common species of the stream sides and the bamboo forest is similar. The proportion of uncommon species (UC) does not appear to be significantly different among habitats.

The diversity of butterfly communtity in four different habitat types in Bu Gia Map National Park is presented in Table 2. The disturbed forest has the greatest species number ( 80 species) and the bamboo forest has the least (40 species). The stream sides have the greatest individual number (644 individuals); the natural forest has the least 
TABLE 1: Species list and abundance of butterflies in different habitats.

\begin{tabular}{|c|c|c|c|c|c|}
\hline \multirow{2}{*}{ No. } & \multirow{2}{*}{ Species } & \multicolumn{4}{|c|}{ Habitats } \\
\hline & & NF & DF & SS & $\mathrm{BR}$ \\
\hline & Papilionidae & & & & \\
\hline 1 & Atrophaneura aidoneus (Doubleday) & 2 & 1 & & \\
\hline 2 & Graphium doson (Felder) & 4 & 1 & 41 & 4 \\
\hline 3 & Graphium sarpedon (Linnaeus) & 3 & & 16 & \\
\hline 4 & Graphium agamemnon (Linnaeus) & 3 & 4 & 7 & \\
\hline 5 & Graphium xenocles (Doubleday) & & 1 & & \\
\hline 6 & Lamprotera meges (Zinken) & & & 2 & \\
\hline 7 & Losaria coon (Fabricius) & 5 & 1 & & 1 \\
\hline 8 & Papilio demoleus (Linnaeus) & & 2 & 1 & \\
\hline 9 & Papilio demolion (Cramer) & 3 & & 1 & 1 \\
\hline 10 & Papilio mahadeva (Moore) & & & 2 & \\
\hline 11 & Papilio memnon (Linnaeus) & 2 & 3 & 3 & \\
\hline 12 & Papilio helenus (Linnaeus) & 14 & 24 & 24 & 6 \\
\hline 13 & Papilio nephenus (Boisduval) & 6 & 2 & 13 & 1 \\
\hline 14 & Papilio paris (Linnaeus) & & 1 & 3 & \\
\hline 15 & Papilio polytes (Linnaeus) & 5 & 5 & 13 & \\
\hline 16 & Papilio protenor (Cramer) & 3 & 1 & & \\
\hline \multirow[t]{2}{*}{17} & Troides helena (Linnaeus) & 2 & 1 & & \\
\hline & Pieridae & & & & \\
\hline 18 & Appias albina (Boisduval) & 7 & 11 & 20 & 7 \\
\hline 19 & Appias lyncida (Cramer) & 2 & 6 & 6 & 18 \\
\hline 20 & Appias nero (Fabricius) & 1 & & 1 & \\
\hline 21 & Catopsilia pomona (Fabricius) & 2 & 49 & 170 & 10 \\
\hline 22 & Cepora nadina Lucus & 3 & 4 & 9 & 11 \\
\hline 23 & Cepora nerissa (Fabricius) & & & 5 & 3 \\
\hline 24 & Delias hyparete (Linnaeus) & & 1 & 1 & \\
\hline 25 & Dercas verhuelli (van de Hoeven) & & 12 & 2 & 5 \\
\hline 26 & Hebomoia glaucippe (Linnaeus) & 5 & 2 & 17 & 3 \\
\hline 27 & Eurema andersoni (Moore) & 2 & 11 & 8 & 35 \\
\hline 28 & Eurema blanda (Boisduval) & & 17 & 45 & 12 \\
\hline 29 & Eurema hecabe (Linnaeus) & & 6 & 23 & \\
\hline 30 & Ixias pyrene (Linnaeus) & 4 & 2 & 8 & 6 \\
\hline 31 & Leptosia nina (Fabricius) & 8 & 12 & 1 & 13 \\
\hline \multirow[t]{2}{*}{32} & Pareronia anais (Lesson) & & 15 & 12 & 5 \\
\hline & Danaidae & & & & \\
\hline 33 & Danaus genutia (Cramer) & & 1 & & \\
\hline 34 & Euploea camaralzeman (Butler) & & 3 & 1 & \\
\hline 35 & Euploea core (Cramer) & & 1 & 1 & \\
\hline 36 & Euploea doubledayi (C. \& R. Felder) & 2 & 5 & 2 & \\
\hline 37 & Euploea mulciber (Cramer) & 5 & 10 & 2 & 6 \\
\hline 38 & Euploea radamanthus (Fabricius) & 10 & 4 & 16 & 1 \\
\hline 39 & Ideopsis vulgaris (Butler) & 1 & & 1 & \\
\hline 40 & Parantica aglea (Stoll) & & & 1 & \\
\hline 41 & Parantica melaneus (Cramer) & & 1 & & \\
\hline \multirow[t]{2}{*}{42} & Tirumala septentrionis (Butler) & & & 3 & \\
\hline & Amathusiidae & & & & \\
\hline 43 & Amathuxidia amython annamensis (Talbot) & 2 & 1 & & \\
\hline 44 & Discophora sondaica (Boisduval) & 2 & & 1 & 1 \\
\hline 45 & Thaumantis diores (Doubleday) & 2 & 1 & & \\
\hline
\end{tabular}


Table 1: Continued.

\begin{tabular}{|c|c|c|c|c|c|}
\hline \multirow{2}{*}{ No. } & \multirow{2}{*}{ Species } & \multicolumn{4}{|c|}{ Habitats } \\
\hline & & $\mathrm{NF}$ & DF & SS & $\mathrm{BR}$ \\
\hline 46 & Thauria lathyi (Fruhstorfer) & 2 & 1 & & \\
\hline \multirow[t]{2}{*}{47} & Stichphthalma eumurai eumurai (Nishimura) & 7 & 10 & 5 & 10 \\
\hline & Satyridae & & & & \\
\hline 48 & Coelites nothis (Westwood) & 5 & & & \\
\hline 49 & Elymnias hypermnestra (Linnaeus) & 1 & 1 & & \\
\hline 50 & Erites medura rotundata (de Niceville) & 8 & & & 1 \\
\hline 51 & Lethe confusa (Aurivillies) & 1 & 3 & 2 & \\
\hline 52 & Lethe kansa (Moore) & 2 & 1 & & \\
\hline 53 & Lethe mekara (Moore) & 2 & 1 & & \\
\hline 54 & Lethe minerva tritogeneia (Frushtorfer) & 2 & 1 & & \\
\hline 55 & Lethe verma (Kollar) & & 1 & & \\
\hline 56 & Melanitis leda (Linnaeus) & 4 & & 1 & \\
\hline 57 & Mycalesis anaxias (Fruhstorfer) & 4 & 2 & 3 & \\
\hline 58 & Mycalesis mineus (Moore) & & 24 & 5 & 20 \\
\hline 59 & Mycalesis sangaica tunicula (Frushtorfer) & & 3 & & 7 \\
\hline 60 & Mycalesis mnasicle perma (Fruhstorfer) & & 4 & & 3 \\
\hline 61 & Ragadia critias (Riley \& Godfrey) & 2 & & & \\
\hline 62 & Ypthima baldus (Fabricius) & 2 & 145 & 4 & 122 \\
\hline \multirow[t]{2}{*}{63} & Ypthima savara savara (Uemura \& Monastyrskii) & 2 & 2 & 1 & \\
\hline & Nymphalidae & & & & \\
\hline 64 & Ariadne merione (Cramer) & & 15 & 5 & 13 \\
\hline 65 & Athyma cama (Moore) & & & 2 & \\
\hline 66 & Athyma nefte (Cramer) & & & & \\
\hline 67 & Athyma ranga (Moore) & & & 2 & \\
\hline 68 & Athyma selenophora (Kollar) & & 7 & 16 & \\
\hline 69 & Cethosia biblis (Drury) & & & 3 & \\
\hline 70 & Chersonesia intermedia (Martin) & & 11 & & 2 \\
\hline 71 & Cirrochroa tyche (Felder) & & 1 & & \\
\hline 72 & Cupha erymanthis (Drury) & 2 & 7 & 1 & 1 \\
\hline 73 & Cyrestis themire (Honrath) & & 7 & 10 & \\
\hline 74 & Cyrestis thyodamas (Doyere) & & 1 & 2 & 1 \\
\hline 75 & Doleschalia bisaltide (Cramer) & & 1 & & 1 \\
\hline 76 & Cynitia cocytus (Fabricius) & 3 & 2 & 7 & 1 \\
\hline 77 & Cynitia lepidea (Butler) & & & 1 & \\
\hline 78 & Euthalia monina (Fabricius) & 3 & 3 & 2 & 1 \\
\hline 79 & Euthalia recta (de Niceville) & 4 & 1 & 2 & 1 \\
\hline 80 & Moduza procris (Cramer) & 6 & & 15 & \\
\hline 81 & Junonia atlites (Linnaeus) & & & 4 & \\
\hline 82 & Junonia almana (Linnaeus) & & 2 & 3 & \\
\hline 83 & Junonia iphita (Cramer) & & 1 & 15 & \\
\hline 84 & Junonia lemonias (Fabricius) & & 1 & & \\
\hline 85 & Laringa horfieldi glaucescens (de Niceville) & & 1 & & \\
\hline 86 & Lasippa tiga (Moore) & & 1 & & \\
\hline 87 & Lebadea martha (Fabricius) & 2 & & & \\
\hline 88 & Lexias dirtea (Fabricius) & 4 & & 2 & \\
\hline 89 & Lexias pardalis (Moore) & 8 & & 15 & \\
\hline 90 & Neptis clinia (Moore) & & 1 & & \\
\hline 91 & Neptis harita (Moore) & 1 & & & \\
\hline 92 & Neptis hylas (Linnaeus) & & 5 & & 2 \\
\hline
\end{tabular}


Table 1: Continued.

\begin{tabular}{|c|c|c|c|c|c|}
\hline \multirow{2}{*}{ No. } & \multirow{2}{*}{ Species } & \multicolumn{4}{|c|}{ Habitats } \\
\hline & & NF & DF & SS & $\mathrm{BR}$ \\
\hline 93 & Neptis nata (Moore) & 2 & 4 & 2 & \\
\hline 94 & Pantoporia hordinia (Stoll) & 1 & 1 & & \\
\hline 95 & Pantoporia aurelia (Staudinger) & & & 1 & \\
\hline 96 & Parasarpa dudu (Westwood) & & 1 & & \\
\hline 97 & Parthenos sylvia (Cramer) & & 1 & 1 & \\
\hline 98 & Polyura athamas (Drury) & & & 2 & \\
\hline 99 & Polyura eudamippus (Doubleday) & 3 & & 9 & \\
\hline 100 & Polyura delphis (Doubleday) & 2 & & 1 & \\
\hline 101 & Rhinopalpa polynice (Cramer) & & & 1 & \\
\hline 102 & Rohana nakuba (Moore) & & 1 & & 1 \\
\hline 103 & Terinos terpander (Hewitson) & & 1 & & 1 \\
\hline 104 & Vagrans egista (Cramer) & 2 & 2 & 5 & \\
\hline 105 & Vindula erota (Fabricius) & 4 & 1 & 8 & \\
\hline 106 & Libythea myrrha (Godart) & & 1 & & \\
\hline & Riodinidae & & & & \\
\hline 107 & Abisara abnormis (Moore) & 2 & & & \\
\hline 108 & Abisara bifasciata (Moore) & 2 & & 1 & \\
\hline 109 & Abisara echerius (Stoll) & & 1 & & 1 \\
\hline 110 & Abisara neophron (Hewitson) & & 1 & & \\
\hline 111 & Paralaxita telesia (Hewitson) & 4 & 2 & 1 & \\
\hline 112 & Zemeros flegyas (Cramer) & & 2 & & 2 \\
\hline
\end{tabular}

Note: Habitats as Figure 1; order of species list of each family by alphabet.

TABle 2: Diversity of butterfly (Papilionoidae, except Lycaenidae) communities in four different habitat types in Bu Gia Map National Park.

\begin{tabular}{lccccc}
\hline Habitat types & Species number $(S)$ & Individual number $(N)$ & Species richness index $(d)$ & Evenness index $(J)$ & Diversity index $\left(H^{\prime}\right)$ \\
\hline NF & 60 & 209 & 11.04 & 0.95 & 3.89 \\
DF & 80 & 508 & 12.68 & 0.74 & 3.23 \\
SS & 73 & 644 & 11.13 & 0.77 & 3.29 \\
BF & 40 & 342 & 6.68 & 0.72 & 2.65 \\
\hline
\end{tabular}

Note: The habitats as Figure 1.

individual number (209 individuals). For all butterfly species (Papilionoidae and Hesperoidae) in the area during the studied period, 193 species were recorded (personal information). The result is similar concerning the species number of Papilionoidae (except Lycaenidae) in each habitat. The natural forest has 105 species, the stream sides have 114 species, the disturbed forest has the most species number (134 species), and the bamboo forest has the least species number (54 species). Species richness index is highest in the disturbed forest and lowest in the bamboo forest. This index is similar when comparing the natural forest and the stream sides. The evenness index is very high in the natural forest where there is not any prominent species with high individual number. The high evenness index of the natural forest leads the high diversity index although it has the least individual number and the lowest species number. The disturbed forest and the stream sides have the greatest species number and individuals, respectively, but not the highest diversity indices. The bamboo forest has the lowest diversity index of butterfly community.

The natural forest has few species but all species of the family Amathusiidae and many species of the family Satyridae (75\% species of the family) (Table 3). The result of this study corresponds with previous work that shows the natural forest supports many species of the families Amathusiidae and Satyridae $[10,17]$. Table 3 shows that the stream sides have all species of the family Pieridae and many species of the family Danaidae ( $80 \%$ species of the family). The bamboo forest has the fewest species of all families with the exception of the family Pieridae.

The similarity of butterfly communities between habitats is displayed in Figure 2. The similarity of butterfly communities among habitats is divided into two groups. One group is the stream sides and the natural forest (50\%), and the other 


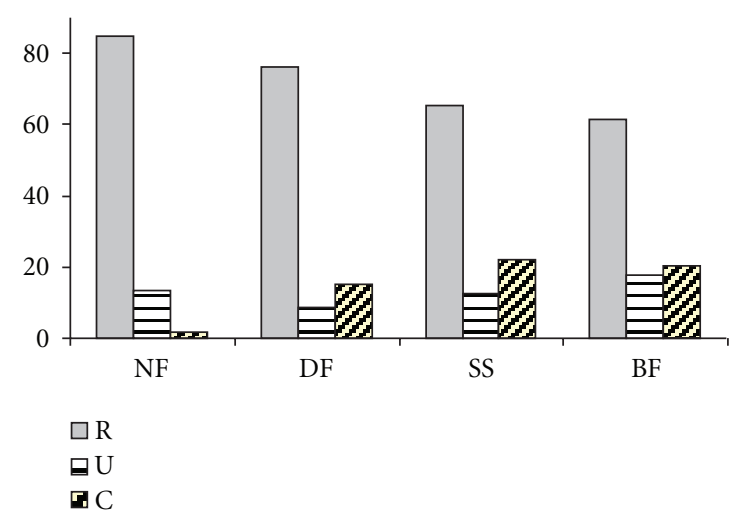

FIGURE 1: Proportion of species abundance (rare, uncommon, common) in each habitat. Note: NF: natural forest; DF: disturbed forest; SS: stream sides in the forest; BF: bamboo forest; R: rare species with individuals less than 5; U: uncommon species with individuals from 6 to 10; C: the common species with individuals more than 10. This is used as ad hoc for this study only.

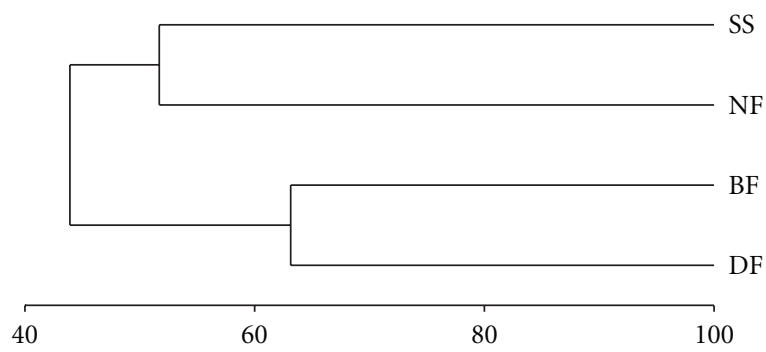

FIGURE 2: The similarity of butterfly communities between habitats. Note: Habitats as Figure 1.

group is the disturbed forest and the bamboo forest (62\%). The disturbed forest and the bamboo forest have similar species composition.

\section{Discussion}

The natural forest has fewer butterfly species than the disturbed forest. Disturbed forests have more species than the stream sides. Bamboo forests have the least species number. This is similar to other studies showing that the disturbed forest has more butterfly species than shrub and grass habitats and agricultural lands [9, 10, 12]. The agricultural lands have the least species number similar to the bamboo forest. Living environment of disturbed forests is nonhomogeneous with a variety of vegetation in the intermediate procession. This consists of opening preferred growing plant species and shrubs. The disturbed forests have more diversity of plants of different processions than the natural forests and the stream sides. The more diverse plants are, the more diverse insects are $[14,25]$. In additional, the disturbed forests have more openings that provide more light and spaces to attract more butterfly species than the natural forests $[15,26]$. The disturbed forests also have more flowering plants that obviously support more butterfly species than
TABLE 3: The percentage of species of families in habitats.

\begin{tabular}{lcccc}
\hline \multirow{2}{*}{ Family } & \multicolumn{4}{c}{ Habitats } \\
& NF & DF & SS & BF \\
\hline Papilionidae & 70.59 & 76.47 & 70.59 & 29.41 \\
Pieridae & 60.00 & 86.67 & 100.00 & 80.00 \\
Danaidae & 40.00 & 70.00 & 80.00 & 20.00 \\
Amathusiidae & 100.00 & 80.00 & 40.00 & 40.00 \\
Satyridae & 75.00 & 75.00 & 37.50 & 31.25 \\
Nymphalidae & 34.88 & 60.46 & 66.11 & 25.58 \\
Riodinidae & 50.00 & 66.67 & 33.33 & 33.33 \\
\hline
\end{tabular}

Note: Habitats as Figure 1.

the natural forest. Other studies also concluded that diversity of species and individuals of butterfly communities increases when natural forests are disturbed; the diversity reaches the highest in moderately disturbed forests but decreases rapidly in urbanized forests $[4,6]$.

The stream sides of the forest have the greatest abundance of butterflies but lower species number than the disturbed forest. The living environment of the stream sides is diversified with vegetation, rocks, sand, and mud and water that attract more butterflies as they land taking water and nutrients from wet rocks, sand, and mud along the stream sides. The wet area supports more butterflies as concluded by Janzen and Schoener than in the tropical forest in the dry season as the study result of Janzen and Schoener [27] that in the tropical forest in dry season. There is greater insect diversity in the wet sites than in the dry sites. In addition, the stream sides in the forest have openings which supports more butterflies. Gaps in the forest have higher butterfly diversity than closed forests [15]. Along the stream, shrub and grass with flowering plants also support more butterflies. The environment of the stream sides is less diverse than the living environment of the disturbed forest. The stream sides have less vegetation layers and simpler vegetation than the disturbed forest, thus the stream sides have less species number than the disturbed forest does. In the disturbed forest, species do not gather in big numbers as they do in the stream side environment. Thus the stream sides have more individuals than the disturbed forest.

The shrub and grass habitat has a high proportion of common butterfly species with a wide geographical distribution range [10]. The stream side habitat is similar to the shrub and grass habitat in which the stream sides have a high proportion of common species with a wide geographical distribution range. This is especially true concerning species of the families Pieridae and Danaidae. Some species prefer wet sand, rocks, and mud along the stream sides. The most abundant species in the stream sides are Catopsilia pomona, Graphium doson, Eurema blanda, and E. hecabe. However, many species of the families Satyridae and Amathusiidae are absent from the stream sides. They are forest species with small geographical distribution ranges $[10,17]$.

The bamboo forest consists of very simple vegetation, mostly bamboo. The less diversity of vegetation results with less diversity of butterflies. Studies show that the more divers 
plants are, the more diverse butterflies and insects are $[1,25]$. The bamboo forest has more individuals than the natural forest due to the fact that the bamboo forest has more individuals than the natural forest due to abundance of some species such as Ypthima baldus, Mycalesis mineus, and Eurema spp. Ypthima baldus is very abundant in the bamboo forest (122 individuals).

Natural forests are richer in abundance of rare species and this metric decreases with increasing habitat opening levels (from natural forest to the stream sides). Conversely, common species increase with increasing forest opening level.

Species composition was dissimilar among habitats, but rather similar between the disturbed forest and bamboo forest, and between the natural forest and the stream sides in the forest. In the study, the stream sides are located in the natural forest and just differ from the natural forest in which the stream sides have openings. Along the stream sides are forest canopies which harbor many species found both in the stream sides and the natural forest. Habitats of the disturbed forest and the bamboo forest are not much similar but many species found in the bamboo forest are also found in the disturbed forest (e.g., species of the families Pieridae and Satyridae). These butterflies fly near the ground. "Thus, the species composition of the disturbed forest and the bamboo forest is similar; the species composition of the natural forest and the stream sides is also rather similar. The butterfly species composition differed between habitat types. This result is similar with Steffan-Dewenter and Tscharntke [28] and $\mathrm{Vu}[10]$.

The result of this study supports the hypothesis that the stream side environment possesses a high abundance of butterflies but not the highest species number and diversity index. The bamboo forest has the least species and diversity index of butterfly community. The stream sides consisting of a mosaic habitat type (natural forest with different layers along the stream sides, openings, and wet sand and rocks) are important environment for the conserving of large abundance of butterflies. However, undisturbed habitats such as the natural forests are important to conserve forest restricted butterfly species (specialist species) [9]. Swengel and Swengel [29] also indicated that long-term vegetative consistency is advised for conservation management of specialist butterflies.

\section{Acknowledgments}

The authors thank the Director and staff of Bu Gia Map National Park for giving permission to study butterflies in the park and Vietnam Russian Tropical Center for letting the authors participate in the biodiversity research. This work was partially funded by National Fund for Science and Technology of Vietnam (Project code: 106.12.15.09).

\section{References}

[1] R. G. DeVries, Outlines of Entomology, Chapman \& Hall/CRC, Boca Raton, Fla, USA, 7th edition, 1992.
[2] H. S. Barlow and I. P. Woiwod, "Moth diversity of a tropical forest in Peninsular Malaysia," Journal of Tropical Ecology, vol. 5, no. 1, pp. 37-50, 1989.

[3] D. R. Morse, N. E. Stork, and J. H. Lawton, "Species number, species abundance and body length relationships of arboreal beetles in Bornean lowland rain forest trees," Ecological Entomology, vol. 13, no. 1, pp. 25-37, 1988.

[4] R. B. Blair and A. E. Launer, "Butterfly diversity and human land use: species assemblages along an urban gradient," Biological Conservation, vol. 80, no. 1, pp. 113-125, 1997.

[5] K. S. Bobo, M. Waltert, H. Fermon, J. Njokagbor, and M. Mühlenberg, "From forest to farmland: butterfly diversity and habitat associations along a gradient of forest conversion in Southwestern Cameroon," Journal of Insect Conservation, vol. 10 , no. 1 , pp. 29-42, 2006.

[6] K. S. Brown, "The use of insects in the study, conservation and monitoring of biological diversity in Neotropical habitats, in relation to traditional land use systems," in Decline and Conservation of Butterflies in Japan III, Proceedings International Symposium on Butterfly Conservation, Osaka, Japan, 1994, S. A. Ae, T. Hirowatari, M. Ishii, and L. P. Brower, Eds., pp. 128149, The Lepidopterological Society of Japan, Osaka, Osaka, Japan, 1996.

[7] H. Fermon, M. Waltert, R. I. Vane-Wright, and M. Mühlenberg, "Forest use and vertical stratification in fruitfeeding butterflies of Sulawesi, Indonesia: impacts for conservation," Biodiversity and Conservation, vol. 14, no. 2, pp. 333350, 2005.

[8] C. H. Schulze, I. Steffan-Dewenter, and T. Tsharntke, "Effect of land use on butterfly communities at the rainforest margin: a case study from Central Sulawesi," in Land Use, Nature Conservation and the Stability of Rainforest Margins in Southeast Asia, G. Gerold, M. Fremerey, and E. Guhardja, Eds., pp. 281-297, Springer, Berlin, Germany, 2004.

[9] V. L. Vu, Biodiversity of butterflies (Lepidoptera: Rhopalocera) and ecological indicator role of some butterfly species in Tam Dao National Park, Vinh Phuc, Ph.D. thesis, Institute of Ecology and Biological Resources, Hanoi, Vietnam, 2008.

[10] L. V. Vu, "Diversity and similarity of butterfly communities in five different habitat types at Tam Dao National Park, Vietnam," Journal of Zoology, vol. 277, no. 1, pp. 15-22, 2009.

[11] K. Spitzer, V. Novotny, M. Tonner, and J. Lepš, "Habitat preferences, distribution and seasonality of the butterflies (Lepidoptera, Papilionoidea) in a montane tropical rain forest, Vietnam," Journal of Biogeography, vol. 20, no. 1, pp. 109-121, 1993.

[12] V. Van Lien and D. Yuan, "The differences of butterfly (Lepidoptera, Papilionoidea) communities in habitats with various degrees of disturbance and altitudes in tropical forests of Vietnam," Biodiversity and Conservation, vol. 12, no. 6, pp. 1099-1111, 2003.

[13] M. S. Warren, "The influence of shade on butterfly numbers in woodland rides, with special reference to the wood white Leptidea sinapis," Biological Conservation, vol. 33, no. 2, pp. 147-164, 1985.

[14] P. W. Price, Insect Ecology, John Wiley \& Sons, New York, NY, USA, 1975.

[15] K. Spitzer, J. Jaroš, J. Havelka, and J. Lepš, "Effect of smallscale disturbance on butterfly communities of an Indochinese montane rainforest," Biological Conservation, vol. 80, no. 1, pp. 9-15, 1997.

[16] E. Pollard, "A method for assessing changes in the abundance of butterflies," Biological Conservation, vol. 12, no. 2, pp. 115134, 1977. 
[17] V. L. Vu, "Ecological indicator role of butterflies in Tam Dao National Park, Vietnam," Russian Entomological Journal, vol. 16, pp. 473-480, 2007.

[18] A. Caldas and R. K. Robbins, "Modified pollard transects for assessing tropical butterfly abundance and diversity," Biological Conservation, vol. 110, no. 2, pp. 211-219, 2003.

[19] M. R. C. Posa and N. S. Sodhi, "Effects of anthropogenic land use on forest birds and butterflies in Subic Bay, Philippines," Biological Conservation, vol. 129, no. 2, pp. 256-270, 2006.

[20] H. H. Pham, An Illustrated Flora of Vietnam. Vol. 1-3, Young Publishing House, Ho Chi Minh city, Vietnam, 1999-2000.

[21] Primer-E Ltd., Primer 5 for Windows. Version 5.2.4, 2001.

[22] L. Chou, Monographia Rhopalocerum Sinensium. Vol. 1-2, Henan Science and Technology Press, Henan, China, 1994.

[23] B. D'Abrera, Butterflies of the Oriental Region. Vol. 1-2, Hill House, Melbourne, Fla, USA, 1982-1984.

[24] A. L. Monastyrskii and A. L. Devyatkin, A System List of Butterflies of Vietnam, Thong Nhat Publishing House, Hanoi, Vietnam, 2003.

[25] K. Spitzer, J. Lepš, and T. Soldan, "Butterfly communities and habitat of seminatural savana in southern Vietnam (Papilionoidae, Lepidoptera)," Acta Entomologica Bohemoslovaca, vol. 84, pp. 200-208, 1987.

[26] J. Hill, K. Hamer, J. Tangah, and M. Dawood, "Ecology of tropical butterflies in rainforest gaps," Oecologia, vol. 128, no. 2, pp. 294-302, 2001.

[27] D. H. Janzen and T. W. Schoener, "Difference in insect abundance and diversity between wetter and drier sites during a tropical dry season," Ecology, vol. 49, pp. 96-110, 1968.

[28] I. Steffan-Dewenter and T. Tscharntke, "Early succession of butterfly and plant communities on set-aside fields," Oecologia, vol. 109, no. 2, pp. 294-302, 1997.

[29] A. B. Swengel and S. R. Swengel, "The butterfly fauna of Wisconsin bogs: lessons for conservation," Biodiversity and Conservation, vol. 19, no. 12, pp. 3565-3581, 2010. 

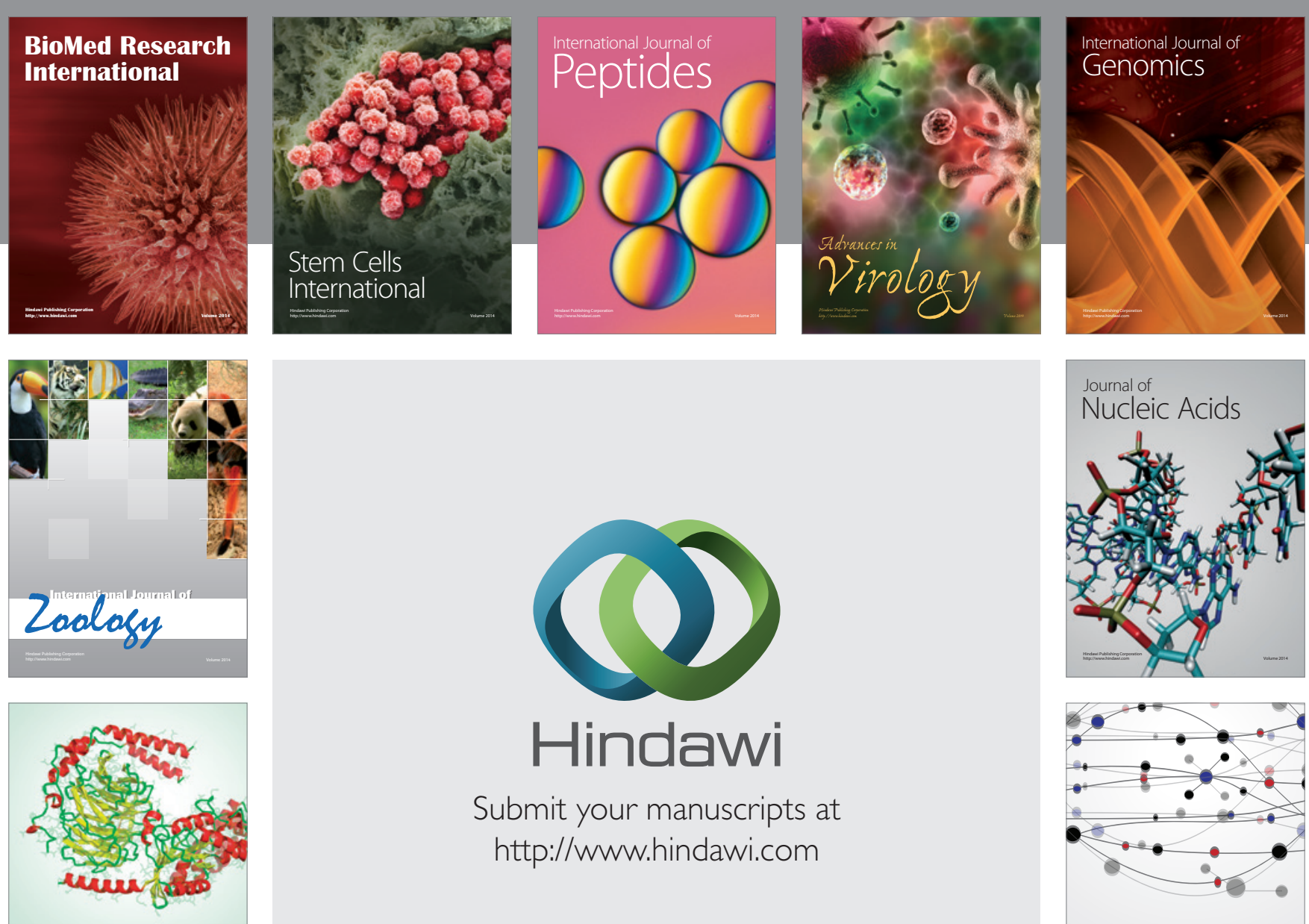

Submit your manuscripts at

http://www.hindawi.com

Signal ${ }^{\text {Jumal }}$ Transduction
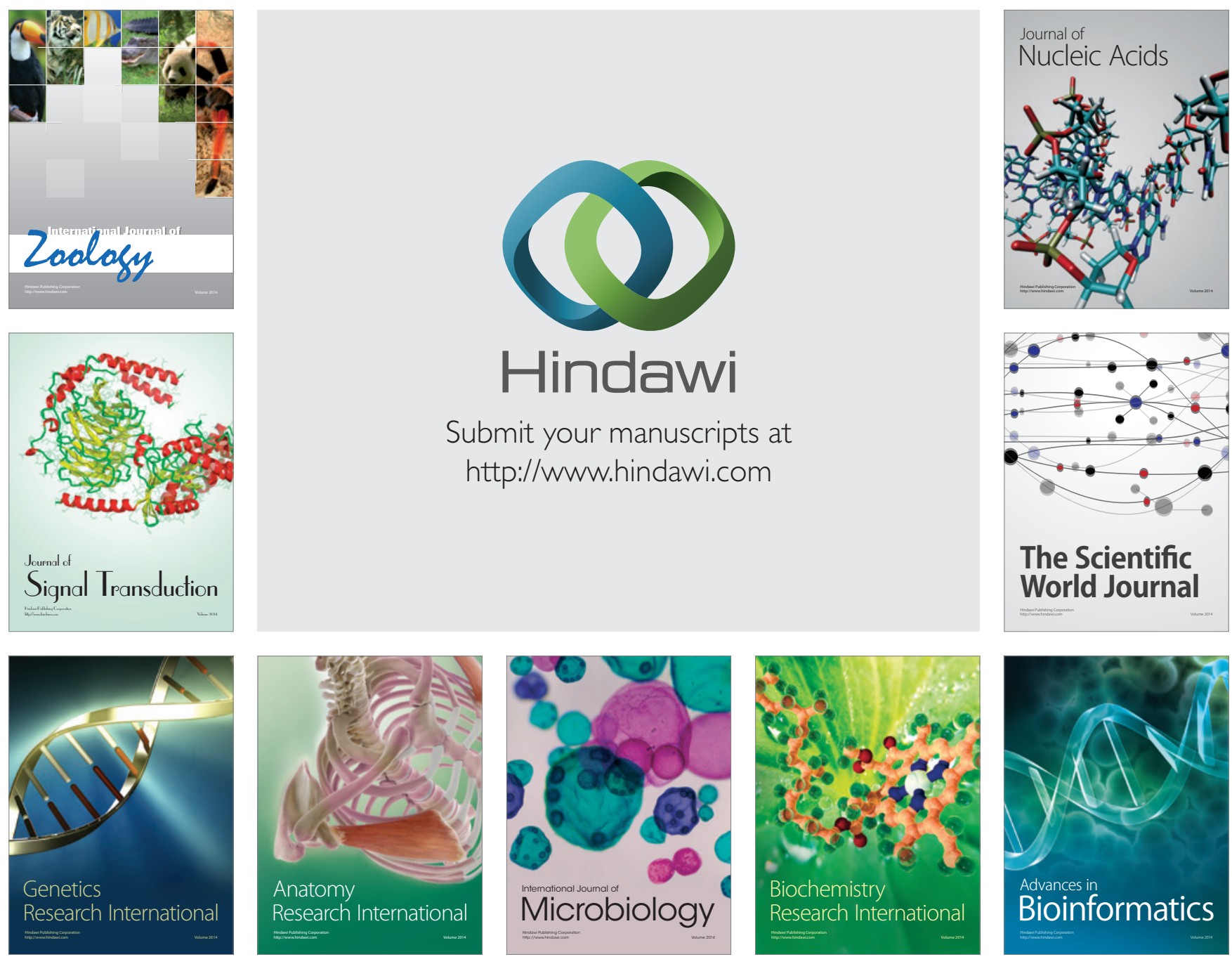

The Scientific World Journal
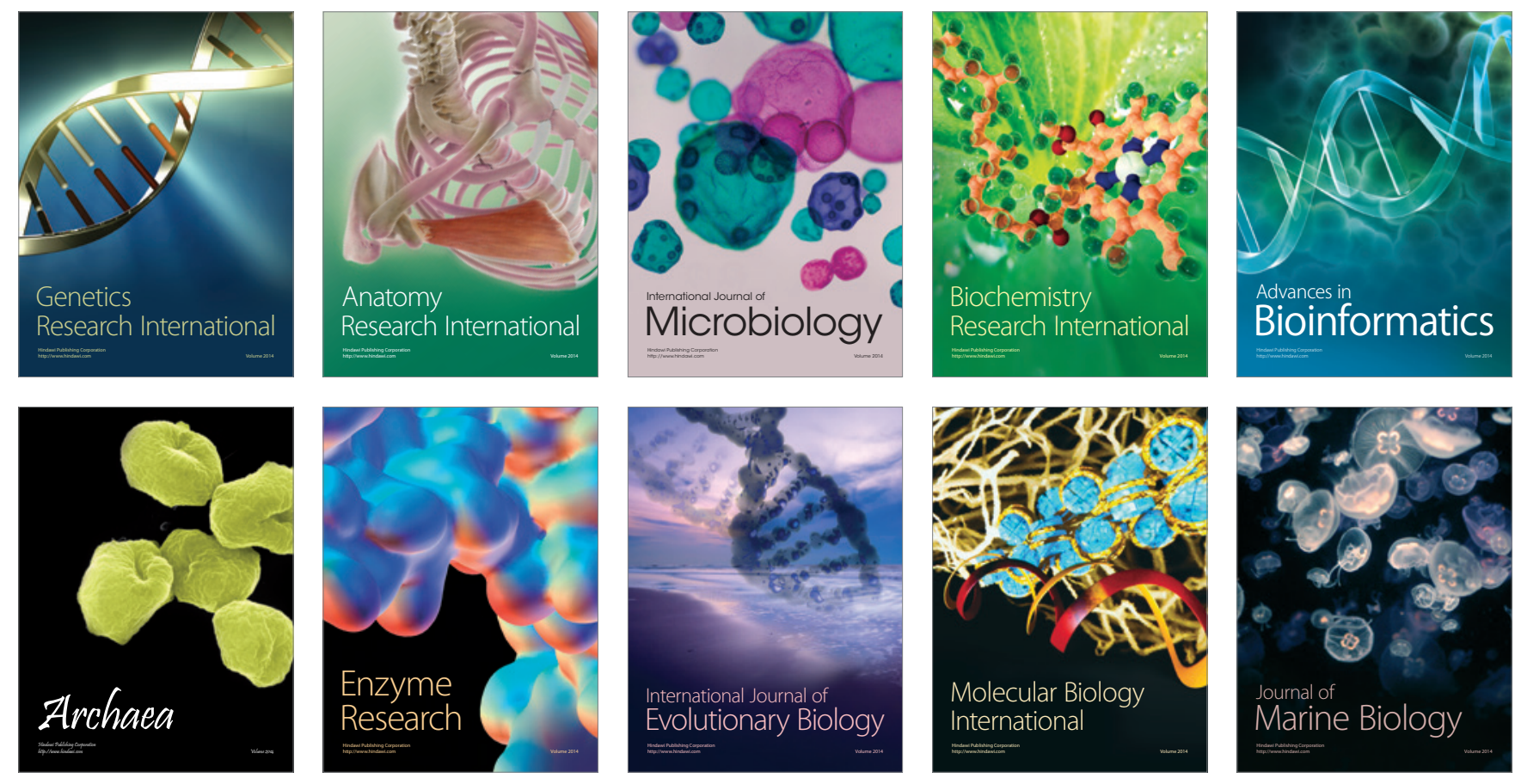